\title{
STUDY OFINTRA OCULAR PRESSURE IN PATIENTS WITH TYPE 2 DIABETES MELLITUS OF UDAIPUR DISTRICT, RAJASTHAN,INDIA
}

\section{Rajendra Kumar Samar ${ }^{1}$, Rishendra Singh Sisodiya *2.}

${ }^{1}$ Assistant professor, Department of Medicine, Pacific Institute of Medical sciences, Udaipur, Rajasthan, India.

${ }^{*}$ Associate professor, Department of Ophthalmology, Pacific Institute of Medical sciences, Udaipur, Rajasthan, India

\section{ABSTRACT}

Background: Intraocular pressure constitutes the most important risk factor for the emergence of glaucoma, a pathology often associated with diabetes mellitus.

Objective: The purpose of the study was to analyze the relationship between intraocular pressure and type 2 diabetes mellitus and to investigate the effects of chronic hyperglycaemia on the intraocular pressure (IOP).

Materials and Methods: We prospectively measured the IOP by applanation tonometry in 100 patients with type 2 diabetes (Group I) and in 100 Normal subject as a control(Group II). The glycosylated haemoglobin (HbA1c) levels of the subjects with diabetes were determined and based on that, they were divided into 3 subgroups as group la with HbA1c levels of $<7 \%(n=40)$; group Ib with HbA1c levels of 7 to $8.0 \%(n=32)$; and group Ic with $\mathrm{HbA1c}$ levels of $>8.0 \%(n=28)$ All the data were expressed as means \pm standard deviations. The statistical analysis was performed by the Student's $t$ test. The correlation between HbA1c and IOP was analyzed by the Pearson's correlation coefficient. A p value of $<0.05$ was considered to be significant.

Results: We observed that the IOP values were higher in the subjects with diabetes (Mean $=21.50 \pm 3.50$ ) than in the age and sex matched control groups. The mean IOP in the groups la, Ib and Ic were $16.32 \pm 2.10,20.54 \pm 2.50$ $\mathrm{mm} \mathrm{Hg}$, and $21.95 \pm 3.20 \mathrm{~mm} \mathrm{Hg}$ respectively. The difference in the IOP between the groups Ib and Ic was found to be statistically significant $(P=.001)$

Conclusion: Diabetic subjects with elevated HbA1c levels exhibited significantly higher IOPs compared to those with lower $\mathrm{HbA1c}$ levels. Findings from this study indicate an association between hyperglycemia and elevated IOP and that poor glycemic control may contribute to increased IOP levels in long-term diabetic patients.

KEY WORDS: Intra-ocular pressure, Type 2 diabetes mellitus, Glaucoma.

Address for correspondence: Dr RishendraSingh Sisodiya, E block,3 BHK,Pacific Institute of Medical sciences Campus, Pacific Institute of Medical sciences, Umarda,Uadipur-313015,Rajasthan,India. E-Mail:rishendrasisodiya@gmail.com

\begin{tabular}{|c|c|c|}
\hline \multicolumn{3}{|c|}{ Online Access and Article Informtaion } \\
\hline \multirow{2}{*}{$\begin{array}{l}\text { Quick Response code } \\
\text { Dol: } 10.16965 / \text { ijims.2019.108 }\end{array}$} & \multicolumn{2}{|c|}{$\begin{array}{l}\text { International Journal of Integrative Medical Sciences } \\
\text { ISSN (P): } 2394 \text { - 6318. ISSN (E): } 2394-4137 \\
\text { www.imedsciences.com }\end{array}$} \\
\hline & $\begin{array}{l}\text { Received: 12-04-2019 } \\
\text { Reviewed: 12-04-2019 }\end{array}$ & $\begin{array}{l}\text { Accepted: 23-04-2019 } \\
\text { Published: 31-05-2019 }\end{array}$ \\
\hline Source of Funding: Self & \multicolumn{2}{|c|}{ Conflicts of interest: None } \\
\hline
\end{tabular}

\section{INTRODUCTION}

Glaucoma is a group of eye disorders that lead to progressive damage to the optic nerve [1]. People with glaucoma can lose nerve tissue, resulting in vision loss. Glaucoma is the secondleading cause of blindness in the U.S. It most often occurs in people over age 40 , although an infant (congenital) form of glaucoma exists [2]. People with a family history of glaucoma, African Americans over the age of 40 and Hispanics over the age of 60 have an increased risk of developing glaucoma. Other risk factors include 
thinner corneas, chronic eye inflammation and taking medications that increase the pressure in the eyes. Glaucoma cannot currently be prevented. But if it is diagnosed and treated early, it can usually be controlled. Medication or surgery can slow or prevent further vision loss. However, vision already lost to glaucoma cannot be restored. That is why the American Optometric Association recommends an annual dilated eye examination for people at risk for glaucoma. Depending on your specific condition, your doctor may recommend more frequent examinations

Diabetes mellitus is a group of metabolic diseases which is characterized by hyperglycaemia, resulting from defects in insulin secretion, insulin action, or both. The chronic hyperglycaemia in diabetes is associated with the long-term damage, dysfunction, and the failure of various organs, especially the eyes, kidneys, nerves, heart, and blood vessels, causing severe systemic complications such as retinopathy, neuropathy and nephropathy [3].In India, as of now, there are over 35 million people with diabetes, a number that is predicted to increase to around 80 million by 2030 [4].

However, some studies have found no association between the same [5]. Therefore, in this study, we tried to observe the intra-ocular pressure behaviour in patients with diabetes mellitus and to find whether there was a significant difference between the intra-ocular pressure values in the patients with diabetes and the control population and also to assess the effects of chronic hyperglycaemia on the intraocular pressure.

\section{MATERIALS AND METHODS}

The present study was conducted at Pacific Institute of Medical sciences, Udaipur, Rajasthan, india from $1^{\text {st }}$ April 2018 to 31 January 2019 at department of ophthalmology in association with department of medicine.

The present study included 100 subjects with diabetes, of the age range of $40-55$ years, who attended the Medicine and Ophthalmology OPD at our institute and 100 age and sex matched healthy control(control group).

Group 1(case group):100 subjects of diabetes mellitus of age group 40-55 years

Group 2(Control group): 100 age and sex matched healthy control

Exclusion criteria: Subjects with systemic hypertension, a family history of glaucoma, a habit of smoking, alcoholism, pregnancy, refractive errors, ocular infection or inflammation or the usage of ocular drugs within the previous three months, a history of ocular surgery, the usage of any medications that would affect the IOP, a history of cardiac diseases and a history of endocrinal diseases or any other major medical problems were excluded from the study. A detailed medical history was collected from all the participants and they underwent a thorough physical examination, screening laboratory tests and screening eye examinations.

Blood sample were collected from all participants for estimation of fasting and post prandial plasma glucose levels, glycated haemoglobin (HbA1C) levels and the serum urea and creatinine levels.

The body mass index was calculated by using the formula, $\mathrm{BMI}=$ Weight in $\mathrm{Kg} /$ (Height in meters). The intra-ocular pressure was measured by using a applanation tonometer.

The screening eye examinations included the assessment of visual acuity, tonometry, slit-lamp examination, and dilated fundus examination. The blood pressure was measured with the subjects in a sitting posture.

Based on HBA1C level,group 1 furture divided ij to 3 subgroup.groupla with $\mathrm{HbA1c}$ levels of $<7 \%(n=40)$; group Ib with HbA1c 7 levels of $8.0 \%(n=32)$; and group Ic with HbA1c levels of $>8.0 \%(n=28)$. All the data were expressed as means + standard deviations. The statistical analysis was performed by the Student's t-test. The correlation between $\mathrm{HbA} 1 \mathrm{c}$ and IOP was analyzed by using the Pearson's correlation coefficient. A p value of $<0.05$ was considered to be significant.

\section{RESULTS}

The physical characteristics of the group I (case ) and thegroup II (control) are shown in [Table/Fig 1].

In thepresent study, the age range of the subjects was $40-55$ years, with the mean age 
being $45.5 \pm 5.0$ years in group I and $43.5 \pm 6.0$ years in group II. Similarly, there was no significant differencein the means of other physical parameters like height, weightand body mass index in the groups I and group II.

A significantincrease in IOP was observed when group I (mean IOP $=21.50 \pm 3.50$ ) was compared with group II (mean IOP $=15.70 \pm 2.90)$ and the $p$ value was 0.001 .

When the IOP was related to the glycaemicstatus and compared between the subgroups, as in [Table/Fig-2],Between Group laand $\mathrm{Ib}$, there is significant difference in the IOP was observed. The IOP in the groups $\mathrm{Ib}$ (mean IOP $=20.54 \pm 2.50)$ and Ic (meanIOP $=$ $21.95 \pm 3.20)$ also showed a significant increase ( $p=0.001$ ), withthat in Ic being comparatively more than that in Ib. when we comparing the IOP level between Group laand Ic ,based on relation to $\mathrm{Hba1c}$ value, then it shows significant difference and $p$ value is $<0.01$.

The correlative analysis showed a statistically significant associationbetween the increased $\mathrm{HbA} 1 \mathrm{C}$ and the IOP in the subjectswith diabetes ( $r=0.82$ and 0.86 respectively in the subgroups Iband Ic).

Table 1: Demographic characteristic of case and control group.

\begin{tabular}{|l|c|c|c|}
\hline \multicolumn{1}{|c|}{ Variable } & $\begin{array}{c}\text { Group I } \\
\text { (Case)(n=100) }\end{array}$ & $\begin{array}{c}\text { Group II } \\
\text { (Control)(n=100) }\end{array}$ & P value \\
\hline Age (yr) & $45.5 \pm 5.0$ & $43.5 \pm 6.0$ & 0.35 \\
\hline Height(mt) & $1.65 \pm 0.23$ & $1.66 \pm 0.15$ & 0.007 \\
\hline Wt(kg) & $67 \pm 2.0$ & $65 \pm 1.8$ & 0.007 \\
\hline Body mass index(BMI) & $24.63 \pm 3.20$ & $23.63 \pm 2.80$ & 0.925 \\
\hline IOP (mmhg) & $21.50 \pm 3.50$ & $15.70 \pm 2.90$ & 0.001 \\
\hline
\end{tabular}

Table 2: Showing comparison of mean IOP between case and control group.

\begin{tabular}{|c|c|c|c|}
\hline Variable & $\begin{array}{c}\text { Group I } \\
\text { (Case)( } \mathrm{n}=100)\end{array}$ & $\begin{array}{c}\text { Group II } \\
\text { (Control)( } \mathrm{n}=100)\end{array}$ & P value \\
\hline $\begin{array}{c}\text { IOP } \\
\text { (mmhg) }\end{array}$ & $21.50 \pm 3.50$ & $15.70 \pm 2.90$ & 0.001 \\
\hline
\end{tabular}

Table 3: Correlation between $\mathrm{Hba1c}$ and intraocular pressure (IOP) in subgroups.

\begin{tabular}{|c|c|c|c|c|}
\hline Sub group & Mean Hba1c \% & Mean IOP & $P$ value & r value \\
\hline Group Ia( $(\mathrm{n}=40)$ & $6.20 \pm 0.25$ & $16.32 \pm 2.10$ & 0.92 & 0.004 \\
\hline Group Ib(n=32) & $7.50 \pm 0.30$ & $20.54 \pm 2.50$ & 0.001 & 0.82 \\
\hline Group Ic(n=28) & $9.20 \pm 0.50$ & $21.95 \pm 3.20$ & 0.001 & 0.86 \\
\hline
\end{tabular}

Graph 1: Showing graphical presentation of Correlation between $\mathrm{Hba} 1 \mathrm{c}$ and intraocular pressure (IOP) in subgroups.

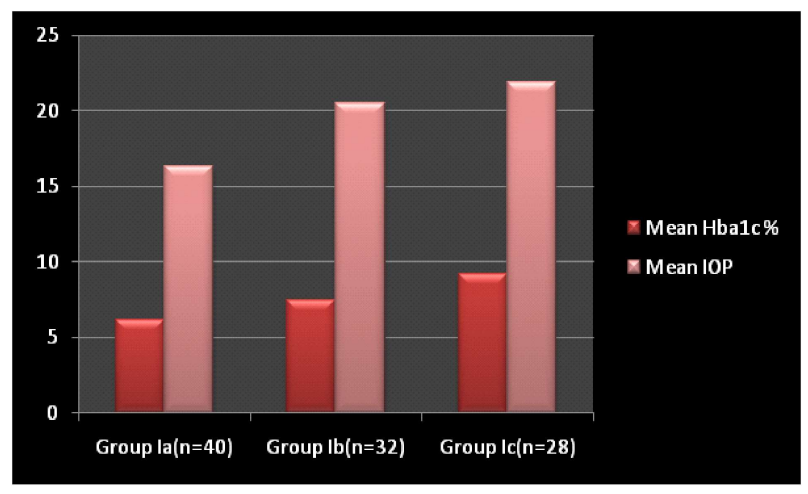

\section{DISCUSSION}

Diabetes is a risk factor for glaucoma, which is the second leadingcause for blindness [5].

However, it has not yet been clearly establishedas to how diabetes affects the intra-ocular pressure. Ourresults showed that the subjects with diabetes, with no previoushi-story of ocular hypertension, had a significantly higher mean IOP $(21.50 \pm 3.50 \mathrm{~mm} \mathrm{Hg})$ than the normal control group $(15.70 \pm 2.90 \mathrm{~mm} \mathrm{Hg})$, which was matched for age, sex and body mass index.These findings are consistent with the conclusions of otherinvestigators $[6,7]$.

The relationship between elevated intra-ocular pressure, diabetes,glycated haemoglobin $(\mathrm{HbA} 1 \mathrm{c})$, and insulin resistance has beenwell documented in several studies $[8,9]$.

Davies et al [10] have reported that the glucose levels in theaqueous humor of patients with diabetes were significantlyhigher $(3.2 \mathrm{mM}$ vs. $7.8 \mathrm{mM}$ ) as compared to the glucose levels inpersons without diabetes. Although the reason for the increasedincidence of open-angle glaucoma in persons with diabeteshas not been elucidated, it is likely that the diabetes associatedchanges in the trabecular extracellular matrix may contributeto a decreased aqueous outflow. A high glucose level inducesfibronectin overexpression in the trabecular meshwork cells andmay contribute to excess fibronectin accumulation in the trabecularmeshwork. High glucose-induced fibronectin upregulation maybe a common biochemical link that on the one hand, contributes to the development of thickened vascular basement membranes in diabetic microangiopathy 
and on the other hand, alters the structural content, compromises resiliency, reduces cellularity, blocks the aqueous outflow in the trabecular meshwork and leads to the development of POAG in persons with diabetes [10].

Diabetes is known to cause microvascular damage and it may affect the vascular auto regulation of the retina and the optic nerve. The development of glaucomatous optic nerve damage, based on the visual field loss and/or the optic disc findings, is more likely to be associated with high intraocular pressure ${ }^{[11]}$.

Besides an increased intra-ocular pressure (IOP), a disturbed microcirculation at the level of the optic nerve head, as well as a primary neurodegenerative component, are thought to contribute to glaucomatous optic neuropathy [12]. In addition to altering the vascular tissues, diabetes mellitus brings about a compromise on the glial and neuronal functions and the metabolism in the retina, which can make the retinal neurons including the retinal ganglion cells, more susceptible to glaucomatous damage [13] Furthermore, diabetes mellitus increases the susceptibility of the retinal ganglion cells to additional stresses which relate to OAG, such as elevated IOP ${ }^{[14]}$. It seems reasonable to consider that a poor glycaemic control in subjects with diabetes mellitus, with a prolonged insult to the retina, would be associated with a higher risk of OAG.

\section{CONCLUSION}

Diabetic subjects with elevated HbA1c levels exhibited significantly higher IOPs compared to those with lower HbA1c levels. Findings from this study indicate an association between hyperglycemia and elevated IOP and that poor glycemic control may contribute to increased IOP levels in long-term diabetic patients.

\section{REFERENCES}

[1]. Coleman AL, Kodjebacheva G. Risk factors for glaucoma needing more attention. Ophthalmol J. 2009;3:38-42.
[2]. Anderson DR. Normal-tension glaucoma (Low-tension glaucoma). Indian J Ophthalmol2011;59:97101.

[3]. Chang YC, Lin JW, Wang LC, Chen HM, Hwang JJ, Chaung LM.Association of intra-ocular pressure with the metabolic syndrome and novel cardiometabolic risk factors. Eye. 2010;24:1037-43.

[4]. Wild S, Roglic G, Green A, Sicree R, King H. The global prevalence of diabetes: estimates for the year 2000 and projections for the year 2030. Diabetes Care. 2004; 27(5):1047-53.

[5]. Carel RS, Korczyn AD, Rock M, Goya I. Association between ocular pressure and certain health parameters. Opthalmology. 1984;91: 311-14.

[6]. Klein BE, Klein R, Linton KL. The intra-ocular pressure in an Americancommunity. The Beaver Dam Eye Study. Invest Opthalmol Vis Sci. 1992;33:222428.

[7]. Sato T, Roy S. Effect of high glucose on fibronectin expression and cell proliferation in trabecular meshwork cells. Invest Ophthalmol Vis Sci. 2002; 43(1):170-5

[8]. Quigley HA. Open-angle glaucoma. N Engl J Med. 1993; 328:1097-06.

[9]. Wise LA, Rosenberg L, Radin RG, Mattox C, Yang EB, Palmer JR, et al., A prospective study of diabetes, lifestyle factors, and glaucoma among AfricanAmerican women. Ann Epidemiol. 2011; 21(6):43039.

[10]. Davies PD, Duncan G, Pynsent PB, Arber DL, Lucas VA. Aqueous humour glucose concentration in cataract patients and its effect on the lens. Exp Eye Res. 1984; 39:605-09.

[11]. Nathan DM, Jurgeon $\mathrm{H}$, Regan S. Relationship between glycated haemoglobin levels and mean glucose levels over time. Diabetologia. 2007; 50(11):2239-44.

[12]. Tielsch JM, Katz J, Quigley HA, Javitt JC, Sommer A. Diabetes, intraocular pressure and primary openangle glaucoma in the Baltimore Eye Survey. Ophthalmology. 1995;102:48-53.

[13]. Kanamori A, Nakamura M, Mukuno H et al. Diabetes has an addictive effect on neural apoptosis in rat retina with chronically elevated intraocular pressure. Curr Eye Res. 2004;28:47-54.

[14]. Nakamura M, Kanamori A, Negi A. Diabetes mellitus as a risk factor for glaucomatous optic neuropathy. Opthalmologica. 2005;219:1-10.

How to cite this article: Rajendra Kumar Samar, RishendraSingh Sisodiya. STUDY OFINTRA OCULAR PRESSURE IN PATIENTS WITH TYPE 2 DIABETES MELLITUS OF UDAIPUR DISTRICT, RAJASTHAN,INDIA. Int J Intg Med Sci 2019;6(3):802-805. DOI: 10.16965/ijims.2019.108 